\title{
1921-1940 M. LAIKOTARPIO LIETUVOS KARIUOMENE்S TYRIMAI
}

\author{
Jonas Vaičenonis, \\ (Vytauto Didžiojo universitetas)
}

Iki šiol neturèjome istoriografinių darbų, skirtų I Lietuvos Respublikos kariuomenès tyrimams, todèl bandysime nuosekliai aptarti tai, kas šia tema iki šiol yra parašyta. Straipsnyje nebus aptarinejjama Lietuvos karo aviacijos ir laivyno istoriografija. Tiek karo aviacija, tiek ir tarpukario laivynas jau sulaukè nemažai studijų bei atskirų mokslinių ir populiarių straipsnių, todèl jiems reikètų paskirti atskirą istoriografini darbą.

Sovietiniais metais Lietuvos kariuomenès vardas buvo tabu. Dẻl šios priežasties turime tik keletą sovietineje Lietuvoje išleistų darbų Lietuvos kariuomenès tema, kurie yra tendencingi ir reikalauja kritinio tyrèjo žvilgsnio. Čia reikia paminèti J. Jurginio darbą „Kauno igulos kareivių sukilimas 1920 metais"1, dokumentų rinkini, parengtą B. Baranausko, „Geležinis vilkas“2, generolo Vinco Vitkausko raštus ${ }^{3}$, kur tik kelios dešimtys puslapių skirta tarpukario Lietuvai. Dar galima paminèti ir Jono Macijausko veikalą, kuriame pristatoma Lietuvos kariuomenés reakcija ị susidariusią situaciją Lietuvą okupuojant sovietams $1940 \mathrm{~m}$. birželị.

Kur kas daugiau Lietuvos kariuomenès palikimui išsaugoti per tuos penkiasdešimt sovietinès okupacijos metų buvo nuveikta lietuvių išeivijoje, ir ypač Jungtinèse Amerikos Valstijose. Ten atgimé ir periodiškai buvo leidžiamas „Kario“ žurnalas, skaitytojus ir tyrejus pasiekė emigravusių Lietuvos kariuomenés karininkų prisiminimai ir pavieniai kariuomenès istorijos fragmentų darbai. Apie juos kalbėsime vèliau.

Per pastarajị dešimtmetị susidomẻjimas I Lietuvos Respublikos kariuomenès istorija labai išaugo. Domimasi ne tik kariuomenès veikeju gyvenimu ir veikla, bet ir atskirų kariuomenès dalių istorija, paramilitarinių organizacijų veikla. Jau keleri metai Vytauto Didžiojo universitete ir Vilniaus universitete bakalauro ir magistro Lietuvos istorijos studijų programų studentai gina diplominius darbus, skir-

\footnotetext{
${ }^{1}$ Jurginis J. Kauno igulos kareivių sukilimas 1920 m. Vilnius, 1955, p. 68.

2 „Geležinis Vilkas“. Vilnius, 1965, p. 107.

${ }^{3}$ Vitkauskas Vincas. Raštai. Vilnius, 1988, p. 172.
} 
tus atskiroms tarpukario Lietuvos kariuomenès istorijos problemoms.

Prieš aptariant šio laikotarpio kariuomenès tyrimų istoriografiją, reikètų susipažinti su šio istorinio tarpsnio periodizacijos problema. Šiandien dar neturime galutinai suformuotos I Lietuvos Respublikos kariuomenès istorijos periodizacijos koncepcijos. Manau, kad būtų tikslinga išskirti keturis 1918-1940 metų laikotarpio kariuomenès istorijos periodus: I - 1918-1920 m.; II - 1921-1926 m.; III 1927-1934 m.; IV - 1935-1940 m. Pirmasis periodas istoriografijoje jau turi nusistovejusisi „Kovų už Nepriklausomybę“ pavadinimą. Antraji galima būtų pavadinti „Kariuomenès reorganizavimo taikos metui“ laikotarpiu, trečiasis - tai „Kariuomenès pertvarkymo planų“ laikotarpis ir ketvirtasis - „Kariuomenès modernizacijos“ laikotarpis. Šie keturi periodai vienaip ar kitaip yra susiję tarpusavyje, todėl kartais yra sunku brèžti juos atskiriančias linijas. Kiekvienas jų taip pat yra glaudžiai susiję ir jiems darè ịtaką to meto Europos ịvykiai.

Pradedant istoriografinę apžvalgą, derètų išskirti keletą knygų, išleistų emigracijoje, kurių dalis buvo pakartotinai išleista pastaraisiais metais, ir I Lietuvos Respublikos kariuomenès tyrejjams tèra antrinis šaltinis. Tai buvusio kariuomenès vado generolo Stasio Raštikio $^{4}$, krašto apsaugos ministrų pulkininko Konstantino Žuko ${ }^{5}$ ir brigados generolo Kazio Musteikio ${ }^{6}$ prisiminimai bei knyga apie generolą Povilą Plechavičių ${ }^{7}$. Be šių leidinių, tyrẻjus pasiekẻ dar keleto Lietuvos kariuomenés karininkų memuarai: Generalinio štabo pulkininko leitenanto Juozo Listopadskio ${ }^{8}$, majoro Stasio Asevičiaus ${ }^{9}$, pulkininko leitenanto Teodoro Reingardo ${ }^{10}$, leitenanto Aleksandro Atučio $^{11}$, Generalinio štabo majoro Antano Malijonio ${ }^{12}$, leitenanto Petro Biržio ${ }^{13}$.

Šalia suminètų memuarų reikia paminèti ir 1935-1940 m. lai-

\footnotetext{
${ }^{4}$ Raštikis St. Kovose dėl Lietuvos. Vilnius, 1990, T. 1, p. 704; 1990, T. 2, p. 688; Raštikis St. Ivykiai ir žmonès. Kaunas, 1996, T. 3. p. 616.; Raštikis St. Lietuvos likimo keliais. Kaunas, 1996, T. 4, p. 792.

${ }^{5}$ Žukas K. Žvilgsnis i praeiti. Vilnius, 1992, p. 334.

${ }^{6}$ Musteikis K. Prisiminimu fragmentai. Vilnius, 1989, p. 64.

${ }^{7}$ Gen. Povilas Plechavičius. Brooklyn, 1978, p. 300.

${ }^{8}$ Listopadskis J. Laisves ir vergijos metai. Vilnius, 1993, p. 199.

${ }^{9}$ Asevičius S. Praeitin atsigręžus. Kaunas, 1993, p. 122.

${ }^{10}$ Reingardas T. Jūrininkas, karininkas, mirtininkas. Šiauliai, 2000, p. 271.

${ }^{11}$ Atutis A. Keturiose kariuomenėse. Vilnius, 1997, p. 107.

${ }^{12}$ Malijonis A. Stipresni už mirtị. Kaunas, 1994, p. 58.

${ }^{13}$ Pupų dẻdè: atsiminimai. Vilnius, 1999, p. 222.
} 
kotarpio tyrimams svarbius, Jungtinèse Valstijose išleistus, Prezidento A. Smetonos adjutanto Vaclovo Śliogerio atsiminimus ${ }^{14}$, puikiai parodančius Prezidento kasdienybę ir jo santykị su jị supančia aplinka.

Turime tik kelis darbus, skirtus kai kurių karininkų biografiniams tyrimams. Kiek didesnio dėmesio čia yra sulaukęs Generalinio štabo pulkininkas Kazys Škirpa ${ }^{15}$ ir tikriausiai vienintele biografinè knyga, parašyta apie archeologą, pulkininką Petrą Tarasenką ${ }^{16}$.

Iki šiol neturime gausesnių Lietuvos kariuomenès tyrimams svarbių pirminių šaltinių publikacijų. Bene didžiausias toks rinkinys - tai Antano Martinionio sudaryta knyga „Žygis į Vilnių 1939 m. spalio 27-29 d." ${ }^{\text {"17 }}$, kurioje šalia publikuojamų archyvinių dokumentų apie Lietuvos kariuomenès žygi i prisiminimai, Respublikos Prezidento, Šaulių sajungos vado, užsienio reikalų ministro kalbos ir poezijos skyrelis, kuriame surinkti eilèraščiai apie Vilnių. Rinkinyje nèra platesnių publikuojamų dokumentų ir pateikiamos medžiagos vertinimų, taip pat pažymètinas ir sudarytojo medžiagos atrankos subjektyvumas. Todẻl aptariant pristatomą problemą, reikia išsamesnių ir nuodugnesnių pirminių šaltinių studijų. 1994 m. Savanoriškoji krašto apsaugos tarnyba pakartojo Vytauto Bulvičiaus $1939 \mathrm{~m}$. išleistą monografiją „Karinis valstybès rengimas $^{\text {“18 }}$, kuri kaip pirminis šaltinis yra svarbi XX a. ketvirtojo dešimtmečio antrosios pusès kariuomenès ir visuomenès rengimo valstybės gynybai tyrimams.

Keletą svarbių kariuomenès istorijai pirminių šaltinių Lietuvos istorijos metraštyje paskelbe Gediminas Rudis. Pirmasis dokumentas, kuriame pateikiama Lietuvos karininkijos nuotaiku $1934 \mathrm{~m}$. analize, datuotas 1934 m. pavasariu. Šis dokumentas - patvirtinimas, kad $1934 \mathrm{~m}$. birželio $7 \mathrm{~d}$. karinis pučas nebuvo kaip perkūnas iš giedro dangaus. Jis liudija, kad maišto dvasia buvo juntama iš anksto ${ }^{19}$. Antroji publikacija - generolo leitenanto Petro Kubiliūno 1934-

\footnotetext{
${ }_{14}$ Šliogeris V. Antanas Smetona. Žmogus ir valstybininkas. Cleveland, 1966, p. 188.

${ }^{15}$ Vašcova Ž. Vienas prieš daugumą. Kazio Škirpos kurta saugios Lietuvos koncepcija // Darbai ir dienos. Kaunas, 2002, T. 30, P. 121-142.; Locaitis L. Plk. K. Škirpos pasiūlymo Vokietijai ir Tarybų Sąjungai garantuoti Lietuvos nepriklausomybę bei paramą kovoje dèl Vilniaus klausimu // Lietuvos istorijos studijos. Vilnius, 1998, T.6, P.72-79.

${ }^{16}$ Steponavičiene D. Petras Tarasenka. Vilnius, 1996, p. 157.

17 Žygis į Vilnių 1939 m. spalio 27-29 d. Vilnius, 1997, p. 364.

${ }^{18}$ Bulvičius V. Karinis valstybès rengimas. Kaunas, 1994, p. 273.

${ }^{19}$ Rudis G. Lietuvos karininkijos nuotaikų 1934 m. analize // Lietuvos istorijos metraštis. 1998 metai. Vilnius, 1999, P. 231-240.
} 
1937 m. malonès prašymai ${ }^{20}$. Publikacijos autoriaus teigimu, šie dokumentai ne tik padeda išsiaiškinti Vyriausiojo štabo ${ }^{21}$ viršininko vaidmenị pučo metu, bet ir nemažai pasako apie vieno iš gabiausių Lietuvos generolų būdą.

Toliau istoriografinę Lietuvos kariuomenès tyrimų apžvalgą bandysime apžvelgti siūlomų periodų tvarka.

Vienas stambiausių leidinių, skirtų kariuomenès istorijai po kovų už Nepriklausomybę laikotarpio iki šiol, yra buvusio Lietuvos kariuomenès karininko Vytenio Statkaus knyga „Lietuvos ginkluotosios pajègos 1918-1940 m."22. Knyga skirta visam tarpukariniam kariuomenès istorijos laikotarpiui ir gana plačiai struktūriškai apžvelgia pati kariuomenès gyvenimą. Gausu joje ir šaltinių, kurių dalis pateikta knygos pabaigoje, taip pat ir memuarinių autoriaus kolegu straipsnių atskiromis temomis. Rengiant knygą dalyvavo net 48 sudarytojo pagalbininkai, kurių 98 procentai - buvę Lietuvos kariuomenès karininkai ir kariai. Autorius pripažista, jog jis, būdamas išeivijoje, negalejo pasinaudoti Lietuvos archyvuose saugomais dokumentais, todèl atsiradę netikslumai yra pagrindinis veikalo trūkumas.

1998 metais, minint Lietuvos kariuomenès 80 metų sukakti, Krašto apsaugos ministerija išleido Gintauto Surgailio monografiją Lietuvos kariuomenè 1918-1998²3. Ši monografija vẻlgi daugiau enciklopedinio pobūdžio, skirta plačiajai visuomenei susipažinti su Lietuvos kariuomenès aštuoniasdešimties metų nueitu keliu, nors joje yra pateikiama nemažai naujų, archyviniais dokumentais paremtų skaičių ir duomenų.

Mažiausiai nagrinètas yra „Kariuomenès reorganizavimo taikos metui“ (1921-1926) laikotarpis. Čia paminètinas tik Algimantas Kasparavičius, kuris paskelbè porą mokslinių straipsnių, ịvardydamas 1926 metų Generalinio štabo viršininko plk. ltn. Kazio Škirpos pastangas pertvarkyti kariuomenę ${ }^{24}$. Pirmajame straipsnyje au-

\footnotetext{
${ }^{20}$ Rudis G. Petro Kubiliūno malonès prašymai (1934-1937) // Lietuvos istorijos metraštis. 1997 metai. Vilnius, 1998 , P. 300-331.

${ }^{21}$ I Lietuvos Respublikos laikais kelis kartus keitèsi šis pavadinimas: Generalinis štabas 19181924, Vyriausiasis štabas 1924-1935, Kariuomenès štabas 1935-1940; todèl tekste vartojami įvairūs pavadinimo variantai pagal laikotarpị.

${ }^{22}$ Statkus V. Lietuvos ginkluotosios pajègos 1918-1940 m. Chicago, 1986, p. 1040.

${ }^{23}$ Surgailis G. Lietuvos kariuomenè 1918-1998. Vilnius, 1998, p. 146

${ }^{24}$ Kasparavičius A. Koalicinès liaudininkų ir socialdemokratų vyriausybès pastangos reorganizuoti kariuomenę 1926 metais // Lietuvos istorijos metraštis, 1993 metai. Vilnius, 1994, P. 58-69.; Kasparavičius A., Mieliauskas T. Lietuvos-Lenkijos santykiai ir Lietuvos kariuomenès modernizavimas 1926-1939 metais // Karo archyvas. Vilnius, 1998, P. 144-161.
} 
torius pristate Lenkijos ir Lietuvos tarpusavio santykių problemą, pateikẻ abiejų valstybių kariuomenių galingumo ịvertinimą ir atskleidè Lietuvos kariuomenès trūkumus. Pateiktose išvadose pasigendama konkretesnio kariuomenės pertvarkymo būtinumo priežasčių îvardijimo. Antrajame straipsnyje vèlgi aptariami Lietuvos ir Lenkijos santykiai, bandoma palyginti 1926 ir 1939 metu Lietuvos kariuomenès materialinę bazę. Čia nerandame perèjimo nuo K. Škirpos iki St. Raštikio reformų, nenurodytos ir paskutiniųjų kariuomenès pertvarkymų priežastys, trūksta platesnio kai kurių kariuomenès rūšių aptarimo. Nesinorètų sutikti ir su teiginiu, kad tik St. Raštikis įtikino vyriausybę, kad kariuomenę reikia perorganizuoti ir perginkluoti. Manome, kad tiek 1926 metų vyriausybé, tiek vėlesnès vyriausybès palaikè pastangas reformuoti kariuomenę. Todèl iki St. Raštikio taip pat buvo stengiamasi įsigyti naujų ginklų ir spręsti ginkluotės sureguliavimo klausimus, bet tai galètų būti jau kito tyrinéjimo tema. A. Kasparavičius monografijoje „Didysis X Lietuvos užsienio politikoje“, pateikdamas gana nemažai skaičių, bando palyginti Lietuvos ir Lenkijos kariuomenių santykị 1926 metais, kur konstatuojamas Lietuvos kariuomenès bejëgiškumas ir reformų būtinumas ${ }^{25} .1926 \mathrm{~m}$. Lietuvos politinès situacijos kontekste pateikiama vyriausybės pozicija, kad valstybẻ turi būti pasirengusi karui su Lenkija ${ }^{26}$. Todèl nepaisant visų sunkumų ir problemų, išskiriamas kariuomenès reorganizavimo būtinumas.

Dar tarpukariu nemažas dėmesys buvo skirtas kariuomenės Švietimo problemai. „Mūsų žinyne“27 buvo skelbti keli karininko Vytauto Steponaičio (ilgamečio „Mūsų žinyno“ redaktoriaus) straipsniai apie švietimo problemas kariuomenèje 1921-1926 metų laiko$\operatorname{tarpiu}^{28}$. Istoriografiniu požiūriu šie tekstai ne tik atskleidžia to lai-

\footnotetext{
${ }^{25}$ Kasparavičius A. Didysis X Lietuvos užsienio politikoje. Vilnius, 1996, P. 224-226.

${ }^{26}$ Ten pat, P. 276.

${ }^{27}$ Mūsų žinynas // Karo mokslo ir istorijos žurnalas, Krašto apsaugos ministerijos literatūros skyriaus leidinys, leistas 1921.III.-1940.V.

${ }^{28}$ Analfabetizmas naujokų tarpe 1921 met. // Mūsų žinynas. 1923, T. 5, Nr. 13, P. 130-132; 1922 metų naujokų išsilavinimas // Mūsų žinynas. 1924, T. 6, Nr. 17, P. 412-415; 1924 metų naujoku išsilavinimas // Mūsų žinynas. 1925, T. 8, Nr. 24, P. 532-535; 1923 m. naujokų išsilavinimas // Mūsų žinynas. 1925, T. 9, Nr. 25, P. 88-91; Steponaitis V. Naujokų išsilavinimas (1921-1924 met.) // Mūsų žinynas. 1926, T. 11, Nr. 33, P. 357-373; Steponaitis V. 1925 metų rudens šaukimo naujokų išsilavinimas ir mokymo rezultatai // Mūsų žinynas. 1926, T. 11, Nr. 33, P. 473476; 1926 metų šaukimų naujoku išsilavinimas // Mūsų žinynas. 1927, T. 12, Nr. 36, P. 354-358; Kareivių švietimas 1926 m. // Mūsų žinynas. 1927, T. 12, Nr. 36, P. 358-362; Steponaitis V. Naujokų išsilavinimas (1925-26 met.) // Mūsų žinynas. 1927, T. 13, Nr. 37, P. 1-8.
} 
kotarpio kariuomenès realijas, požiūrị i šaukiamụjų naujokų išsilavinimą ir švietimą, bet yra ir puikus šaltinis nagrinejjant kariuomenés tautinès sudèties problemą.

Plačiau nenagrinètas ir 1927-1934 metų kariuomenès istorijos laikotarpis. Apie ji šiandien informaciją pateikia tik memuarinè ir kraštotyrinè medžiaga. Čia reikia paminèti Vidmanto Jankausko monografija apie Nepriklausomos Lietuvos generolus ${ }^{29}$, kurioje yra pateiktos daugelio Lietuvos kariuomenès generolų biografinès apybraižos. Jose ne tik žvelgiama ị žmogaus gyvenimą bet ir paryškinami atskiri kariuomenés gyvenimo, tarp kurių rasime ir fragmentiškai aptariamus pertvarkymus kariuomenėje, o kalbant apie gen. Petrą Kubiliūną, akcentuojami 1934 metų pučo įvykiai. Bet tai ne tyrinėjimai, o šaltiniai ateities studijoms.

Tik fragmentiškai apie kariuomenès reikalus užsimena $\mathrm{A}$. Eidintas monografijoje „Antanas Smetona“ ${ }^{\text {" }}$. Knygoje yra skyrius, pavadintas „Prezidentas, kariuomenè ir diplomatija“, kuriame, remiantis V. Šliogerio, J. Augustaičio ir K. Musteikio atsiminimais ${ }^{31}$, šiek tiek kalbama apie santykius su St. Raštikiu.

Vienas darbų, apimančių visą A. Smetonos biografiją ir skirtų jo aplinkai, politikai, santykiams su visuomene, - profesoriaus L. Truskos monografija „Antanas Smetona ir jo laikai““32. Tekste rasime nemažai informacijos apie poperversminio $1926 \mathrm{~m}$. gruodžio $17 \mathrm{~d}$. laikotarpio A. Smetonos santykius su kariuomenès vadovybe ir karininkija, karo padèties įvedimą ir apskritai karininkijos vaidmeni A. Smetonos valdymo piramideje.

Pats naujausias darbas, telpantis i ǐsios istoriografijos rèmus, istoriko Ričardo Čapo „Plečkaitininkai““33, skirtas Lietuvos opozicinių partijų kovai prieš autoritarinį režimą, susikūrusį po 1926-ųjų perversmo. Studijoje nemažai dėmesio skirta ir kariuomenei aptariant ne tik aukštesniuosius ir žemesniuosius karininkus, bet ir viršilas, vachmistrus, puskarininkius ir liktinius karius, kalbant apie pastangas juos patraukti ị kovą prieš perversmą ịvykdžiusius ir valdžią paèmusius karininkus ir jų statytinius A. Smetoną ir A. Voldemarą.

\footnotetext{
${ }^{29}$ Jankauskas V. Nepriklausomos Lietuvos generolai. Vilnius, 1998, p. 280.

${ }^{30}$ Eidintas A. Antanas Smetona. Vilnius, 1990, p. 245.

${ }^{31}$ Ten pat, P. 152-161.

32 Truska L. Antanas Smetona ir jo laikai. Vilnius, 1996, p. 411.

33 Čepas R. Plečkaitininkai. Vilnius, 2000, p. 273.
} 
Apie paskutiniji 1935-1940 metų laikotarpị kalbèta šiek tiek daugiau, tačiau dažniausiai jis minimas aptariant visą tarpukario Lietuvos kariuomenès istorijos laikotarpi nuo 1918 iki 1940 metu arba nušviečiant tik kariuomenès situaciją 1939-1940 metais. Čia paminètini Gintautas Surgailis ir Arvydas Pociūnas, kurie 1992 m. dalyvavo ekspertų komisijoje, sudarytoje prie Lietuvos derybų su Rusija delegacijos, vadovaujamoje dr. E. Nazelskio ir dr. E. Jovaišos. Ši grupe nustatẻ Sovietų okupacijos metu padarytą žalą Lietuvos kariuomenei. Šių tyrimu pagrindu buvo paskelbta ir nemažai straipsnių tiek populiarioje, tiek ịvairioje mokslineje spaudoje ${ }^{34}$. Paminètina ir G. Surgailio parašyta knygelẻ „Lietuvos Respublikos kariuomenė 1918-

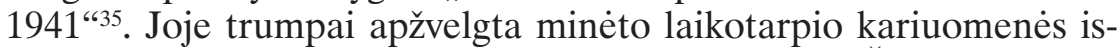
torija pristatant ją sovietinès okupacijos išvakarèse. Čia taip pat pasigendama platesnès kariuomenés modernizacijos analizès. To paties autoriaus monografijoje „Lietuvos kariuomenès vadai“"36 $\mathrm{yra}$ pateikta ir gen. St. Raštikio biografija, o šalia kitų faktu, tik trumpai pristatoma kariuomenės reformą ir kai kurie jos rezultatai.

Šio straipsnio autoriaus yra aptarta Lietuvos kariuomenès mo-

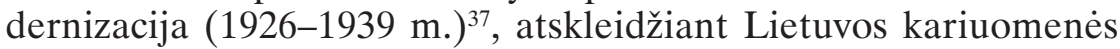
reformų būtinumą, pasirengimą jas atlikti ir atlikto darbo rezultatus Europos kontekste. Šis darbas užpildo kai kurias mūsų kariuomenès istorijos spragas, tačiau taip pat atskleidžia dar daugeli ateities tyrimų krypčių. Ateityje tam tikri tyrimai turètų būti skirti kariuomenès štabo veiklos istorijai, mobilizacinių planų rengimo, raidos ir igyvendinimo istorijai, valstybės gynybinių planų analizei.

Skirtingomis tarpukario kariuomenès istorijos temomis rašè ir daugelis to laikotarpio amžininkų - karininkų, kurių prisiminimai yra tikrai vertingi. Iš jų galima būtų paminèti St. Biručio ${ }^{38}$, J. Meis-

\footnotetext{
${ }^{34}$ Surgailis G. Tarpukario Lietuvos kariuomenè // Kardas. 1994, Nr. 1-2, P. 24-25; Surgailis G. Lietuvos karo laivynui - 60 // Karys. 1995, Nr. 7, P. 26-27; Pociūnas A. Lietuvos kariuomenė 1939-1940 metais // Kardas. 1994, Nr. 7-8, P. 16-18; Pociūnas A. Lietuvos kariuomenès ginkluote ir karinė pramonė 1939-1940 metais // Mokslas ir technika. 1993, Nr. 4, P. 30-31;

${ }_{35}$ Surgailis G. Lietuvos Respublikos kariuomenè 1918-1941. Vilnius, 1996, p. 32.

${ }^{36}$ Surgailis G. Lietuvos kariuomenès vadai. Vilnius, 1992, p. 192.

${ }^{37}$ Vaičenonis J. Lietuvos kariuomenès modernizacija (1926-1939) // Darbai ir Dienos. Kaunas, 2000, T. 21, P. 131-176.

${ }^{38}$ Birutis St. Lietuvos kariuomenès ginklavimas // Karys. 1991, Nr. 5, P. 255-262; Nr. 6, P. 308-310.
} 
ter $^{39}$, J. Pyragiaus ${ }^{40}$, St. Buzo ${ }^{41}$ ir kitų tekstus. Pats St. Raštikis savo atsiminimų tomuose ${ }^{42}$ apie reformas kariuomeneje kalba ne itin daug. Trumpai pristatęs reformų planą, jis toliau aptaria kariuomenès vadovybės įstatymą, mokymą, kariuomenès ir visuomenès santykius, Šaulių sajungos reformą ir tai, kas buvo nuveikta per tuos kelerius metus iki 1939-ųjų.

Žvelgiant ị visą aptariamą laikotarpi, galima pastebèti, kad beveik nėra tyrimų, skirtų atskirų tarnybų, dalinių ar karinių struktūrų istorijai. Čia vẻlgi galima išskirti tik keletą atliktų darbų: G. Surgailio sintetinị darbą, skirtą karinèms-visuomeninèms organizacijoms ${ }^{43}$, Aušros Jurevičiūtès tyrimą, skirtą Lietuvos kariuomenès kūrẻjų savanorių sajungos kūrimo problemai ${ }^{44}$, ir Romo Juzefovičiaus tyrimą, skirtą Karo mokslų draugijos veiklai ${ }^{45}$. Kiek plačiau yra aprašyta kariuomenès šarvuotosios technikos ${ }^{46}$ (autoriai A. Pociūnas, Liucijus Suslavičius, Vytautas Grigoraitis), kariuomenès automobilių ${ }^{47}$ ir sunkvežimių ${ }^{48}$ isto-

\footnotetext{
${ }^{39}$ Meister J. Lietuvos laivynas // Karys. 1975, Nr. 1, P. 6; Nr. 2, P. 50.

${ }^{40}$ Pyragius J. Kovosiu, kol gyvas. Kaunas, 1993, p. 200; Pyragius J. Lietuvos karo aviacijos tarnyboje // Plieno sparnai. 1998, Nr. 5, P. 56-61.

${ }^{41}$ Buzas S. Brigados generolas Kazys Musteikis // Karys. 1994, Nr. 11, P. 12; Buzas S. Lietuvos karo mokyklai 75-eri // Karys. 1994, Nr. 6, P. 12-14.

${ }^{42}$ Raštikis St. Kovose dèl Lietuvos. Vilnius, 1990, p. 704; Raštikis St. Ivykiai ir žmonès. Kaunas, 1996, p. 616.

${ }^{43}$ Surgailis G. Karinès-visuomeninès organizacijos Lietuvoje 1918-1940 m. // Karo archyvas. Vilnius, 1997, T. 14, P. 48-99.

${ }^{44}$ Jurevičiūtè A. Lietuvos kariuomenès kūrejjų savanorių sajungos kūrimas // Karo archyvas. Vilnius, 2001, T. 16, P. 137-145.

${ }^{45}$ Juzefovičius R. Istorinè švietejjiška karo mokslų draugijos veikla 1923-1933 // Karo archyvas. Vilnius, 2002, T. 17, P. 181-194.

${ }^{46}$ Pociūnas A. Buvo pasiruošę ginti Lietuvą... Šarvuočiai // Tẻviškès žinios. 1989, Nr. 140; Pociūnas A. Buvo pasiruošę ginti Lietuvą ... Šarvuotieji traukiniai ir tankai // Tẻviškès žinios. 1989, Nr. 145; Pociūnas A. Buvo pasiruošę ginti Lietuvą... Tanku išvežè Rusijon // Tèviškès žinios. 1990, Nr. 9; Pociūnas A. Lietuvos kariuomenès šarvuočių rinktinè 1919-1940 metais // Trimitas. 1990, Rugsejjis, Nr. 3 (1024). P. 4, 6; Pociūnas A. Lietuvos kariuomenès šarvuočiai (tankai) // Trimitas. 1991, Nr. 18, 1991, Nr. 19; Pociūnas A. Lietuvos lengvas tankas - LLT / / Trimitas. 1992, Nr. 3; Pociūnas A. Šarvuoti traukiniai Lietuvos kariuomenèje // Karys. 1994, Nr. 5; Suslavičius L. Šarvuoti automobiliai „Landsverk 182“ // Karys. 1993, Nr. 9, P. 27; Suslavičius L. Tankas Lietuvai // Karys. 1992, Nr. 2, P. 42-43; Grigoraitis V. Tankai ir tanketès (Lietuvos kariuomenès technika (1)) // Mobilis. 2000-2001, Nr. 12/1, P. 88-93; Grigoraitis V. Šarvuočiai (Lietuvos kariuomenès technika (3)) // Mobilis. 2001, Nr. 3, P. 40-45; Grigoraitis V. Traktoriai ir vilkikai (Lietuvos kariuomenès technika // Mobilis. 2001, Nr. 8, P. 40-43.

${ }^{47}$ Grigoraitis V. Lietuvos kariuomenès automobiliai 1919-1940 // Lietuvos archyvai. Vilnius, 1999, T. 12. P. 23-47.

${ }^{48}$ Grigoraitis V. Lietuvos kariuomenès technika: sunkvežimiai // Karo archyvas. Vilnius, 2001, T. 16, P. 151-182; Grigoraitis V. Lietuvos kariuomenès sunkvežimiai // Mobilis. 2000, Nr. 6, P. $40-45$.
} 
rija, 1919-1930 m. artilerija ${ }^{49}$ (autorius A. Pociūnas), kariuomenès uniformos $^{50}$ (autorius J. Vaičenonis), karo dvasininkijos tarnyba Lietuvos kariuomeneje 1919-1929 m. ${ }^{51}$ (autorius Rytas Narvydas), karo topografijos tarnyba ${ }^{52}$ (autorius Algirdas Antanas Gliožaitis), ginklu dirbtuvès Linkaičiuose ${ }^{53}$ (autorius Jurgis Mikaila). Tačiau dauguma šių tekstu yra paskelbta populiariojoje spaudoje. Cia reikia paminèti ir visai neseniai išejusią Jono Rudoko monografiją „Prarastieji Lietuvos talentai“ ${ }^{“ 54}$, kuri yra paskirta karininkų, dirbusių karo mokslo srityje, atminimui įamžinti. Knygoje pateikiama Lietuvos ginklavimosi istorija, tyrimų laboratorijos kūrimas, Lietuvos karinès pramonès darbai ir problemos. Antrojoje knygos dalyje sutalpintos trumpos daugiausiai nusipelnusių karo mokslo raidai Lietuvoje karininkų biografinès apybraižos. Turime šiandien publikuotą ir statistinį tekstą, skirtą Lietuvos kariuomenès 1920-1939 m. laikotarpio skaičiams ${ }^{55}$, kuriame rasime ne tik iki šiol ịvairioje literatūroje pateikiamų skaičių istoriografinę apžvalgą ir vertinimą, bet kiekvienų metų kiekvieno mėnesio kariuomenès sudèties statistiką. Straipsnyje yra pateiktas skyrelis kariuomenès tautinès ir religinès sudèties bendrosioms tendencijoms aptarti. Ši medžiaga turètų tapti kiekvieno būsimo tarpukario kariuomenès istorijos tyrejo pagalbininku.

Baigiant dar reikia paminèti šiuo metu atliekamą daugiatomio enciklopedinio leidinio Lietuvos kariuomenes karininkai: 1918$1953 \mathrm{~m}$. rengimo darbą. $2001 \mathrm{~m}$. buvo išleistas pirmasis tomas ${ }^{56}$, i kurị buvo įdèti karininkų pavardžių abėcèliniai sąvadai: Lietuvos karininkai 1918-1940 m.; karo kapelionai 1918-1940 m.; 1940 m. spalio mèn. XV laidos aspirantai; $1940 \mathrm{~m}$. lapkričio mèn. XXII laidos kariūnai; pasipriešinimo kovų dalyviai, kuriems Lietuvos Prezidento

\footnotetext{
${ }^{49}$ Pociūnas A. Lietuvos kariuomenès artilerija 1919-1930 m. // Karys. 1999, Nr. 8.

${ }^{50}$ Vaičenonis J. Lietuvos kariuomenès uniformos raida 1918-1940 metais // Karo archyvas. T. 14, Vilnius, 1997, P. 100-112; Vaičenonis J. Lietuvos kariuomenès uniformos istorija 19181940 m. // Lietuvos archyvai, (Apie Lietuvos kariuomenę). Vilnius, 1999, P. 49-63.

${ }^{51}$ Narvydas R. Karo dvasininkijos tarnyba Lietuvos kariuomeneje (1919-1929) // Kardas. 2001, Nr. 1 (400), P. 36-37.

${ }^{52}$ Gliožaitis A. A. Lietuvos kariuomenès geodezijos, topografijos ir kartografijos darbų, atliktų 1920-1940 metais, apžvalga // Karo archyvas. Vilnius, 1997, T. 14, P. 113-175.

${ }^{53}$ Mikaila J. Ginklų dirbtuvès Linkaičiuose // Karys. 1984, Nr. 1, P. 29-31, Nr. 2, P. 75-78, Nr. 3, P. 123-125, Nr. 4, P. 171-173, Nr. 5, P. 222-224.

${ }^{54}$ Rudokas J. Prarastieji Lietuvos talentai. Vilnius, 2001, P. 399.

${ }^{55}$ Vaičenonis J. Lietuvos kariuomenès skaičiai 1920-1939 m. // Karo archyvas. Vilnius, 2002,

T. 17 , P. $144-180$.

${ }^{56}$ Lietuvos kariuomenès karininkai 1918-1953. T. 1, Vilnius, 2001, p. 351.
} 
dekretais ir Krašto apsaugos ministerijos ịsakymais 1997-2000 metais buvo suteiktas karininko laipsnis; karininkai, žuvę kovose už Nepriklausomybę 1919-1923 m.; karininkai, pašalinti iš tarnybos kariuomenejje 1940 m. birželio mèn. - $1941 \mathrm{~m}$. sausio mèn.; Lietuvos liaudies kariuomenès politiniai vadovai; karininkai, nukentėję nuo sovietinio genocido 1940-1941 m.; karininkai, kalinti Štuthofo koncentracijos stovykloje 1943-1945 m.; karininkai savisaugos daliniuose; karininkai Vietinejje rinktinëje; karininkai Tèvynès apsaugos rinktineje; karininkai Raudonojoje armijoje Antrojo pasaulinio karo metais; karininkai, 1940-1945 m. emigravę i Vakarus; karininkai 19401953 metų ginkluoto pasipriešinimo dalyviai.

Apibendrinant reikia pažymėti, kad iki šiol nèra plačiau tyrinètos péstininkų ir kavalerijos pulkų istorijos, kariuomenès kasdieninis gyvenimas, tradicijos, šventės. Beveik nepaliesta karo komendantūrų istorija. Čia galima būtų atskirai ištirti ir pateikti Kauno komendantūros istoriją. Taip pat išsamiau netyrinètos paramilitarinès kariuomenès organizacijos. Kiekviena iš jų galètų sulaukti atskirų tyrimų ir publikacijų. Neturime ir išsamių tiek $1926 \mathrm{~m}$. gruodžio $17 \mathrm{~d}$. perversmo, tiek $1934 \mathrm{~m}$. birželio $7 \mathrm{~d}$. karinio pučo ịvykių studijų, kuriose būtų apžvelgtas ir ịvertintas kariuomenès vaidmuo. Kiek didesnio dèmesio turètų susilaukti ir aptariamojo laikotarpio Lietuvos šaulių sajungos, kuri nuo 1935 metų buvo Lietuvos kariuomenès sudedamoji dalis, istorijos tyrimai. Taip pat vertètų pamąstyti apie chrestomatinio I Lietuvos Respublikos kariuomenès svarbesnių dokumentų rinkinio parengimą ir publikavimą.

İteikta 2002-09-26 


\section{SANTRUMPA}

\section{1-1940 m. laikotarpio Lietuvos kariuomenès tyrimai}

Iki šiol neturejjome istoriografinių darbų, skirtų I Lietuvos Respublikos kariuomenès tyrimams, todèl šiame straipsnyje bandoma nuosekliai aptarti tai, kas šia tema iki šiol yra parašyta. Straipsnyje neaptarinejama Lietuvos karo aviacijos ir laivyno istoriografija, nes jiems reikètų paskirti atskirą istoriografini darbą.

Šiandien dar neturime galutinai suformuotos I Lietuvos Respublikos kariuomenès istorijos periodizacijos koncepcijos, todėl autoriaus teigimu tikslinga išskirti keturis 1918-1940 metų laikotarpio kariuomenès istorijos periodus : I - 1918-1920 m. ; II - 19211926 m. ; III - 1927-1934 m. ; IV - 1935-1940 m. Remiantis šia periodizacija bandoma pateikti ir atliktų kariuomenès tyrimų istoriografinę apžvalgą.

Be iki šiol išleistų apibendrinančių enciklopedinio pobūdžio Vytenio Statkaus (Lietuvos ginkluotosios pajègos 1918-1940 m.) ir Gintauto Surgailio (Lietuvos kariuomené 1918-1998) monografijų, skirtų tarpukario Lietuvos kariuomenei, šiandien kiek plačiau yra aprašyta kariuomenès šarvuotosios technikos (autoriai Arvydas Pociūnas, Liucijus Suslavičius, Vytautas Grigoraitis), kariuomenès automobilių ir sunkvežimių istorija, 1919-1930 m. artilerija (autorius Arvydas Pociūnas), kariuomenės uniformos (autorius Jonas Vaičenonis), karo dvasininkijos tarnyba Lietuvos kariuomenėje 1919-1929 m. (autorius Rytas Narvydas), karo topografijos tarnyba (autorius Algirdas Antanas Gliožaitis), ginklų dirbtuvès Linkaičiuose (autorius Jurgis Mikaila), karinès-visuomeninès organizacijos (autoriai Gintautas Surgailis, Aušra Jurevičiūtė, Romas Juzefovičius). Turime šiandien publikuotą ir statistinị tekstą, skirtą Lietuvos kariuomenès 1920-1939 m. laikotarpio skaičiams (autorius Jonas Vaičenonis). Taip pat reikia paminėti šiuo metu atliekamą daugiatomio enciklopedinio leidinio Lietuvos kariuomenès karininkai: 1918-1953 m. rengimo darbą.

Žvelgiant ì visą aptariamą laikotarpị, galima pastebėti, kad beveik nèra tyrimų, skirtų atskirų Lietuvos kariuomenės tarnybų, dalinių ar karinių struktūrų istorijai. Taip pat reikia pažymėti, kad iki šiol nèra plačiau tyrinètos péstininkų ir kavalerijos pulkų istorijos, kariuomenès kasdieninis gyvenimas, tradicijos, šventès. Beveik ne- 
paliesta karo komendantūru istorija. Kiek didesnio dẻmesio turètų susilaukti ir aptariamojo laikotarpio Lietuvos šaulių sajungos, kuri nuo 1935 metu buvo Lietuvos kariuomenès sudedamoji dalis, istorijos tyrimai. Taip pat vertetuc pamąstyti apie chrestomatinio I Lietuvos Respublikos kariuomenès svarbesnių dokumentų rinkinio parengimą ir publikavimą. 


\title{
RÉSUMÉ
}

\section{Les études sur l'armée lituanienne de l'entre-deux-guerres 1921-1940}

\author{
Jonas Vaičenonis \\ Université Vytautas le Grand
}

Jusqu'à présent, nous n'avons pas de travaux historiographiques, concernant des recherches sur l'armée de la Première République de Lituanie, c'est pourquoi nous essayons dans cet article d'examiner avec cohérence ce qui a été écrit sur ce thème jusqu'à présent. L'historiographie de la marine et de l'aviation militaires lituaniennes n'est pas étudiée dans cet article, car il faudrait leur octroyer un travail historiographique distinct.

Aujourd'hui, nous n'avons pas encore définitivement de former une conception de la périodisation de l'histoire de l'armée de la Première République de Lituanie, c'est pourquoi, selon l'auteur, il est juste de considérer quatre périodes dans l'histoire de l'armée pendant la période 1918-1940: I- 1918-1920; II- 1921-1926; III- 19271934; IV-1935-1940. En s'appuyant sur cette périodicité, on a tenté de donner un aperêu historiographique des études réalisées sur l'armée. Sans compter la publication les monographies générales de Vytenis Statkus (Les forces armées lituaniennes 1918-1940) et de Gintautas Surgailis (L'armé lituanienne 1918-1998) de nature encyclopédique, consacrées à l'armée lituanienne de l'entre-deux-guerres, on décrit plus largement aujourd'hui les techniques des blindés de l'armées (auteurs: Arvydas Pociūnas, Liucijus Suslavičius, Vytautas Grigoraitis), l'histoire des automobiles et des camions de l'armée, l'artillerie 1919-1930 (auteur: Arvydas Pociūnas), les uniformes militaires (auteur: Jonas Vaičenonis), le service aumônier dans l'armée lituanienne 1919-1929 (auteur: Rytas Narvydas), le service de topographie guerrière (auteur: Algirdas Antanas Gliožaitis), les armureries de Linkaičiai (auteur: Jurgis Mikaila), les organisations militaro-publiques (auteurs: Gintautas Surgailis, Aušra Jurevičiūtė, Romas Juzefovičius). Nous avons aujourd'hui un texte publié et statistique, concernant les chiffres de l'armée lituanienne pendant la période 1920-1939 (auteur: Jonas Vaičenonis). Il faut aussi mentionner le 
travail de préparation de la publication encyclopédique en plusieurs volumes réalisé actuellement Les officiers de l'armée lituanienne : 19181953.

Considérant toute la période étudiée, il est possible de s'apercevoir qu'il n'y a presque pas d'études consacrées à l'histoire des différents services, unités ou structures militaires. Il faut aussi noter que l'histoire des régiments d'infanterie et de cavalerie, la vie quotidienne, les traditions et les fźtes de l'armée n'ont pas été largement étudiées jusqu'à présent. On devrait accorder une attention bien plus grande aux recherches historiques sur l'Union des Francs-Tireurs (Šauliai) lituaniens de la période examinée, qui a été une partie à part entičre de l'armée lituanienne à partir de 1935. 


\section{SUMMARY}

\section{Studies of the Lithuanian Army in the Period from 1921 to 1940}

\section{Jonas Vaičenonis}

So far there have been no historiographic studies focusing on the Lithuanian army during the period of the first Lithuanian Republic. Therefore, the present article attempts to overview exhaustively what has been written on the topic. The present paper, however, does not include the historiography of the military aviation and navy, because they require a separate investigation.

There still does not exist a clearly set division of the periods of the Lithuanian army in the first Lithuanian Republic. The author of the present article suggests distinguishing four periods of the army from 1918 to 1942, i.e. (1) 1918-1920, (2) 1921-1926, (3) 19271934 and (4) 1935-1940. On the basis of these distinctions of the army periods, other historiographic studies of the Lithuanian Army are overviewed.

The studies of the Lithuanian Army between the two World Wars include two encyclopaedic monographs by Vytenis Statkus (Lithuanian armed forces in 1918-1940) and Gintautas Surgailis (the Lithuanian army in 1918-1998). The issues that are analysed in greater detail encompass such topics as the history of armoured troops (by Arvydas Pociūnas, Liucijus Suslavičius and Vytautas Grigoraitis), the history of military automobiles and trucks, the artillery of the army in 1919-1930 (by Arvydas Pociūnas), military uniforms (by Jonas Vaičenonis), the service of war clergy in the Lithuanian army in 19191929 (by Rytas Narvydas), the service of war topography (by Algirdas Antanas Gliožaitis), ammunition workshops in Linkaičiai (by Jurgis Mikaila) and military-public organisations (by Gintautas Surgailis, Aušra Jurevičiūtè and Romas Juzefovičius). A statistical analysis of the Lithuanian army in 1920-1939 was carried out and published by Jonas Vaičenonis. It also should be noted that currently a voluminous encyclopaedic study Officers in the Lithuanian Army in 19181953 is being prepared.

It can be observed in the list above that there exist no studies of specific services of the Lithuanian army and historical overviews 
of certain military units. A number of other under-investigated topics include the history of infantry and cavalry troops, as well as the everyday life, traditions and festivals of the army. There have been very scarce investigations in the field of the history of commandant's headquarters. The history of the Rifle Union in the period under analysis also requires more exhaustive studies, since it has been a part of the Lithuanian army since 1935. Another issue that should be seriously considered is the necessity to prepare and publish a collection of the most important documents of the army of the first Lithuanian Republic. 